\title{
Flavonoids Induce Migration Arrest and Apoptosis in Detroit 562 Oropharynx Squamous Cell Carcinoma Cells
}

\author{
Arkadiusz Dziedzic $^{1, *(\mathbb{D}}$, Robert Kubina ${ }^{2} \mathbb{D}$, Robert D. Wojtyczka ${ }^{3} \mathbb{D}$, Marta Tanasiewicz ${ }^{1}$, Elena Maria Varoni ${ }^{4}(\mathbb{D}$ \\ and Marcello Iriti ${ }^{5}$ (D)
}

Citation: Dziedzic, A.; Kubina, R.; Wojtyczka, R.D.; Tanasiewicz, M.; Varoni, E.M.; Iriti, M. Flavonoids Induce Migration Arrest and Apoptosis in Detroit 562 Oropharynx Squamous Cell Carcinoma Cells. Processes 2021, 9, 426. https:// doi.org/10.3390/pr9030426

Academic Editor: Bonglee Kim

Received: 25 January 2021

Accepted: 22 February 2021

Published: 27 February 2021

Publisher's Note: MDPI stays neutral with regard to jurisdictional claims in published maps and institutional affiliations.

Copyright: (C) 2021 by the authors. Licensee MDPI, Basel, Switzerland. This article is an open access article distributed under the terms and conditions of the Creative Commons Attribution (CC BY) license (https:// creativecommons.org/licenses/by/ $4.0 /)$.
1 Department of Conservative Dentistry with Endodontics, Medical University of Silesia, Pl. Akademicki 17, 41-902 Bytom, Katowice, Poland; martatanasiewicz@sum.edu.pl

2 Department and Institute of Pathology, School of Pharmacy and Division of Laboratory Medicine in Sosnowiec, Medical University of Silesia, ul. Ostrogórska 30, 41-200 Sosnowiec, Katowice, Poland; rkubina@sum.edu.pl

3 Department of Microbiology and Virology, School of Pharmacy and Division of Laboratory Medicine in Sosnowiec, Medical University of Silesia, ul. Jagiellońska 4, 41-200 Sosnowiec, Katowice, Poland; rwojtyczka@sum.edu.pl

4 Department of Biomedical, Surgical and Dental Sciences, University of Milan, via Beldiletto, 20142 Milan, Italy; elena.varoni@unimi.it

5 Department of Agricultural and Environmental Sciences, University of Milan, via G. Celoria 2, 20133 Milan, Italy; marcello.iriti@unimi.it

* Correspondence: adziedzic@sum.edu.pl; Tel.: +48-32-39560-13

\begin{abstract}
Despite advances in the treatment of head and neck squamous cell carcinoma (HNSCC), the morbidity remains at a high level due to the resistance of SCC cells to chemotherapeutics. This study aimed to determine and compare the magnitude of the flavonoids' effectiveness in activating apoptosis and migration arrest in HNSCC cells in vitro. Methods: Head and neck SCC cells of the Detroit 562 line were exposed to a range of concentrations (5-100 $\mu \mathrm{M}$ ) of quercetin (Que), hesperidin (Hes) and rutin (Rut) for 24 and $48 \mathrm{~h}$. The SCC cell viability and migration rate were investigated using cytotoxicity and migration inhibition assays. Muse Cell Analyzer flow cytometry was utilized to quantitatively assess the apoptosis rate of Detroit 562 cells exposed to Que, Hes and Rut. The morphology of the SCC cells was evaluated via hematoxylin-eosin staining. Results: The viability diminishment of the Detroit 562-line cells treated with Que, Hes and Rut for $48 \mathrm{~h}$ revealed a significant dose-dependent trend, relatively equal for three substances, whereas the most noticeable cytotoxic effect observed for Hes. Exposure to Hes and Rut exhibited a dose-dependent increased proportion of apoptotic SCC cells, at either necrosis or late apoptosis stage. Detroit 562 SCC migration rate and cells motility were halted for the $100 \mu \mathrm{M}$ dose of Hes and Que. The comparative results elucidated that Hesperidin and Quercetin achieved a more potent reduction of Detroit 562 migration at $24 \mathrm{~h}$. Conclusions: Hesperidin, rutin and quercetin are capable of inducing apoptosis and migration arrest in the Detroit 562 cell line to various extents, resulting in proapoptotic attenuating effects at different magnitudes.
\end{abstract}

Keywords: squamous cell carcinoma; head and neck cancer; flavonoids; apoptosis; cell viability; cell migration

\section{Introduction}

Cancer rates and morbidity are increasing in Europe, including malignant tumours in the head and neck region, with the ageing population and lifestyle accounting for most of the increase [1]. Particularly, oral cancer rates are projected to accelerate quickly in males, as the analysis predicts its especially marked rise [1,2]. Oral cancer is the most common type of head and neck cancer and more than $90 \%$ of oral cancers are either oral or oropharyngeal squamous cell carcinoma (SCC). A major clinical dilemma is chemotherapy efficiency targeted for head and neck squamous cell carcinoma (HNSCC) due to the 
variable cell sensitivity of squamous cell cancers within the oral-facial-head region $[3,4]$. Over the last decade, well-known and brand-new compounds of natural origin have been investigated to potentially support the protocols of chemoprevention and/or standard chemotherapy [5-9].

The inability to successfully complete cancer treatment utilizing a standard surgical approach due to an advanced stage of HNSCC and/or resistance of SCC cells to conventional chemotherapy and/or radiotherapy leads to a continuous search for new compounds with cytostatic activity and minor side effects. The concept of chemoprevention focuses on the preventing of initiation and arrest/inhibition of cancer cells grown in the early stages of carcinogenesis, preventing the development of cancer before it becomes capable of invading surrounding tissue $[10,11]$. Among the substances with chemoprevention activity the most identifiable are folic acid, vitamin $C$ and A, vitamin E, carotene, and many other substances of natural origin, including flavonoids, such as hesperidin, rutin and quercetin [5,7,11-14]. Flavonoids, a non-homogeneous group of polyphenolic metabolites widely present in fruits, vegetables, and plant foods, have numerous activities, including a well-known reported anticancer effect. While some forms of HNSCC, especially nasopharynx cancer, are difficult to treat efficiently utilizing a standard oncological approach due to access, location, and their spreading pattern within vital parts of head and neck area, the target-specific application of biologically active compounds might improve the HNSCC protocol and bring novel methods of adjunct treatment.

The beneficial anti-proliferative, antioxidative and anti-inflammatory effects of flavonoids, flavonoid glycosides and other phenolic compounds on cancerous cells have been assessed in vitro in preclinical studies, with the concept of using them as potential chemopreventive agents or synergistic additives with standard chemotherapeutics [7,15-23]. Despite current knowledge about the flavonoid biological properties towards different malignant cells, including oral and esophageal squamous cell carcinoma [24-27], there is a lack of studies available regarding the inhibition of pharynx squamous carcinoma cell growth by exposure to rutin, hesperidin and/or quercetin. The single case-control study was conducted by Rossi et al. in Italy, who examined the relationship between general flavonoids intake and oral and pharyngeal cancer risk, with no specific selection of certain types of flavonoid compounds [28]. The only available results of an in vitro study [29] demonstrated quercetin's effects on the viability of wild-type and mutant p53 nasopharyngeal carcinoma cell lines, HK1 and CNE2.

Indicating the compounds that selectively stimulate apoptosis is currently a new developing strategy for the chemoprevention of cancer. It is known that bioactive substances contained in natural products, including medicinal plants, fruits and bee propolis-which are among the substances said to have anti-cancer activity-are flavonoids. These mainly include apigenin, luteolin, galangin, rutin, quercetin and hesperidin, phenolic acids, and esters, particularly of caffeic and ferulic acid $[10,27,30,31]$. The common flavonoids such as quercetin $\left(3,3^{\prime}, 4^{\prime}, 5,7\right.$-pentahydroxyflavone), the glycoside rutin-combining flavonol quercetin and the disaccharide rutinose $(\alpha$-L-rhamnopyranosyl- $(1 \rightarrow 6)-\beta$-D-glucopyranose) and hesperidin - a flavanone glycoside - is widely distributed in plant, foods, and beverages. Furthermore, apart from apparent cytotoxic effect towards cancer cells, these polyphenolic compounds exhibit varied biological actions such as antioxidant, radical-scavenging, anti-inflammatory and antibacterial, acting as immune-modulators [5,10,13,27,31-33].

The nature of the neoplasia/metaplasia process is to reduce the sensitivity of cells to apoptosis by activating molecular signals [34-36]. In this study, the ultimate goal was to compare the cytotoxic and proapoptotic effects of selected flavonoids on the viability and apoptosis rate in pharynx HNSCC cancer cells of the Detroit 562 line using standardized in vitro conditions. The Detroit 562 epithelial cell line derives from pleural fluid in a person diagnosed with pharyngeal primary SCC cancer. These cells exhibit type B glucose-6phosphate dehydrogenase expression and immunoperoxidase staining positive for keratin. To the best of our knowledge, this is one of the first in vitro studies that compares the cytotoxic activity of three different phenolic compounds, hesperidin, rutin, and quercetin, 
towards SCC cells originating from the pharynx region. As the clinical significance of these flavonoids remains under-reported and under-documented, particularly in the field of head and neck cancer chemoprevention and anti-neoplasm action, the study herein was aiming to enhance scientific interest in the biological interactions of natural flavonoids compounds, commonly present in diets from all over the world, regardless of region and origin.

\section{Materials and Methods}

\subsection{Cell Line Culture Conditions and Reagents}

Human Detroit 562 cells were purchased from the European Collection of Authenticated Cell Cultures (catalogue no. 87042205, European Collection of Authenticated Cell Cultures, Porton Down, Salisbury, England). Eagle's minimum essential medium (EMEM), fetal bovine serum (FBS) and penicillin-streptomycin cocktails were purchased from Thermo Scientific (Rockford, IL, USA). Bioflavonoids compounds rutin (Rut), quercetin (Que) and hesperidin (Hes) were obtained from Sigma-Aldrich (St. Louis, MO, USA) and the Muse Annexin \& Dead Cell kit and the Muse Count and Viability kit is manufactured by Millipore (Darmstadt, Germany).

Pharynx cancer cell line Detroit 562 was grown according to the manufacturer's specification using EMEM supplemented with 10\% FBS. The cells were cultured in bottles of $75 \mathrm{~cm}^{2}$ (PAA) with the addition of antibiotics: $100 \mathrm{IU} / \mathrm{mL}$ penicillin, $100 \mu \mathrm{L} / \mathrm{mL}$ streptomycin and $0.25 \mu \mathrm{L} / \mathrm{mL}$ amphotericin B. Cells were cultured in a $\mathrm{CO}_{2}$ incubator at $37^{\circ} \mathrm{C}$ and in a saturated steam atmosphere with $5 \%$ carbon dioxide $\left(\mathrm{CO}_{2}\right)$.

\subsection{Cell Viability via (4,5-Dimethylthiazol-2-yl)-2,5 Diphenyltetrazolium Bromide (MTT) Assay}

The cytotoxicity of test compounds for the throat cancer cells was measured using MTT (3-(4,5-dimethylthiazol-2-yl)-2-5 diphenyl tetrazolium bromide). The ability of cells to reduce MTT is a measure of viability. Following $24 \mathrm{~h}$ and $48 \mathrm{~h}$ incubation of the cells with the Rut, Hes and Que compounds, the medium was removed and the MTT reagent was added to each well to a final concentration of $1 \mathrm{mg} / \mathrm{mL}$. This was then incubated for $4 \mathrm{~h}$ at $37^{\circ} \mathrm{C}$ in a $5 \% \mathrm{CO}_{2}$. After this time, the supernatant was decanted and the water-insoluble formazan crystals were dissolved in $150 \mu \mathrm{L}$ of dimethyl sulfoxide (DMSO). An absorbance reading was carried out with an ELISA plate reader (BioTek, VT, USA) at a wavelength of $570 \mathrm{~nm}$. The procedure was analogical with the cells after a $48 \mathrm{~h}$ period since the addition of the test compounds.

\subsection{Cell Apoptosis via Muse ${ }^{\circledR}$ Annexin V and Dead Cell Assay; Analysis of Viability and Cell Death Using Flow Cytometry}

The degree of apoptosis in the cell population is an important parameter of the state of cells' health and is characterized by significant morphological changes. The characteristic features of apoptosis are changes in the structure of the cell membrane. It leads to abnormal asymmetry in the distribution of membrane phospholipids. Herein, the Muse Cell Analyzer was used to assess apoptosis using annexin V and Dead Cell assay, based on the detection of phosphatidylserine (PS) on the surface of apoptotic cells.

For the analysis of flow cytometry, Detroit 562 cells $5 \times 10^{5}$ cells/well were seeded in 6-well plates and left for $48 \mathrm{~h}$ to obtain logarithmic growth. The cells were incubated in a complete culture medium containing 50 and $100 \mu \mathrm{M}$ of flavonoids compounds for 24 and $48 \mathrm{~h}$. For the apoptotic assay, $1 \times 10^{6}$ cells in suspension were transferred into a fresh tube and further incubated with $100 \mu \mathrm{L}$ of the Annexin V and Dead Cell reagent (Millipore, United Kingdom) for $20 \mathrm{~min}$ at room temperature. The apoptosis rate was analyzed using the Muse Cell Analyzer (emission max: yellow-red-576 nm and $680 \mathrm{~nm}$; excitation max: $532 \mathrm{~nm}$ ).

\subsection{Microscopic Evaluation of Detroit 562 HNSCC Carcinoma Cells}

The SCC cells were inoculated onto 2-chamber microscopic culture vessels (Lab-Tek ${ }^{\mathrm{TM}}$, Waltham, MA, USA) in the amount of 1000 Detroit 562 cells per well for $24 \mathrm{~h}$ to allow 
logarithmic growth. Next, the flavonoids in specific concentrations were added to the media and left for 24 and $48 \mathrm{~h}$, respectively, depending on the time of the experiment. After a pre-defined time, $96 \%$ ethanol was used for $12 \mathrm{~h}$ to fix investigated cells. Then, they were hydrated in a series of decreasing concentrations, $99.6 \%, 96 \%, 90 \%, 80 \%, 70 \%$ and $50 \%$, following a standard H\&E staining protocol. The plates were irrigated with the PBS (30 $\mathrm{min}$ ) and were immersed in eosin. Then they were rewashed with PBS solution again and dehydrated using increasing concentrations of ethanol: $50 \%, 70 \%, 80 \%, 90 \%, 96 \%$, $99.6 \%$. Lastly, the plates were immersed in a mixture of ethanol/xylene $(50 \% \mathrm{vs.} 50 \%)$ and then in pure xylene, ready to be analyzed under a microscope (Leica, Wetzlar, Germany).

\subsection{Wound Healing Assay—Detroit 562 Cancer Cells Migration Assessment}

The effect of Hes, Rut and Que on the migration rate of Detroit 562 SCC cells was measured by wound healing assay, to assess the dynamic process of movement/motility and the replacement of removed cells within a space created on a monolayer area or cell growth ("original wound"). The inhibitory result is expected when the wound does not close or closes to a minimal extent, hence the original area remains uncovered or only slightly changed, preferably for a prolonged time. This effect confirms that the investigated compound arrests the migration/motility of the SCC cells.

The cells of the Detroit 562 line were disseminated in T25 bottles and cultivated following the manufacturer's instructions, until a confluence of over $95 \%$ was obtained. After reaching the required confluence, the cells were starved overnight in a culture medium with reduced FBS content in serum (up to 1\%) to inhibit the proliferation of cells. After that time, the cells were scratched with a $10 \mu \mathrm{L}$ pipette tip, marking two vertical lines and a horizontal one, generating two crosses with a proper distance from each other and the bottle edge. The cells were thoroughly washed using PBS in order to remove cells detached by scratching as well as necrotic cells. Subsequently:

1. For control cells, the culture medium was added to the bottle and was left for $24 \mathrm{~h}$ in $\mathrm{CO}_{2}$ incubator with the JuLi Br system (NanoEntek Inc., Seoul, Korea) for the continuous monitoring of cells. Photographs were taken at 10-min intervals.

2. For treated samples, the cells were cultivated in a culture medium with the addition of the studied flavonoids in the concentration of $1 / 4 \mathrm{IC}_{50}$. The cells were kept for $24 \mathrm{~h}$ in a $\mathrm{CO}_{2}$ incubator with the JuLi Br system.

3. For pre-incubated cells with flavonoids, after the cell starvation period the culture medium was replaced and the new culture medium was added, containing flavonoids in the concentration of $1 / 4 \mathrm{IC}_{50}$, for a period of $24 \mathrm{~h}$. After that time, the cells were scratched and thoroughly washed utilizing PBS. After that, the cells were cultivated on a medium with flavonoids in a concentration of $1 / 4 \mathrm{IC}_{50}$ for $24 \mathrm{~h}$. TScratch software by CSELab, Zurich, Switzerland and the CorelDRAW Graphics Suite 2019 Corel, Canada) were used for the analysis. The initial surface of the wound was measured. Subsequently, the wound surface measurements were analyzed after $6 \mathrm{~h}, 12 \mathrm{~h}$ and $24 \mathrm{~h}$. The migration coefficient was presented as the percentage of "open wound area" compared with the initial outline, in the time of " 0 " $h$.

\subsection{Statistical Analysis}

The obtained laboratory results are presented as means \pm SD from three separate experiments carried out in quadruplicates $(n=12)$ for cytotoxicity assessment. The experimental stages were repeated three times. The mean and standard deviation of the cumulative data from all experiments were presented on the bar graphs. Statistical analysis utilized the Mann-Whitney U test and Kruskal-Wallis test, with Dunn's multiple comparisons correction. Analyses were performed using Statistica v10 (Stat Soft, St Tulsa, OK, USA). The experimental means were compared to the values of non-exposed SCC cells harvested in a similar manner. A $p$-value of less than 0.05 was considered statistically significant. 


\section{Results}

\subsection{Quercetin, Hesperidin and Rutin Decrease SCC Detroit 562 Cell Viability}

The effect of inhibiting proliferation of cell line Detroit 562 with Que, Hes, and Rut was assayed using an MTT (3-[4,5-dimethylthiazol-2-yl]-2,5-diphenylotetrazolium bromide) cell viability assay. The human skin fibroblasts line was used as a control to assess the potential effect of the bioactive compounds on the normal, epithelial non-malignant cells (Figure 1C,D). As a result of the initial pilot study, the concentration of $200 \mu \mathrm{M}$ was not used as it resulted in necrosis of the normal human dermal fibroblasts NHDF. The survival rate of the Detroit 562 cell line following exposure to the Hes, Rut, and Que compounds showed a significant dose-dependent diminishing trend above a concentration of $25 \mu \mathrm{M}$ after $48 \mathrm{~h}$, with the least noticeable effect observed for Que (Figure 1A,B).

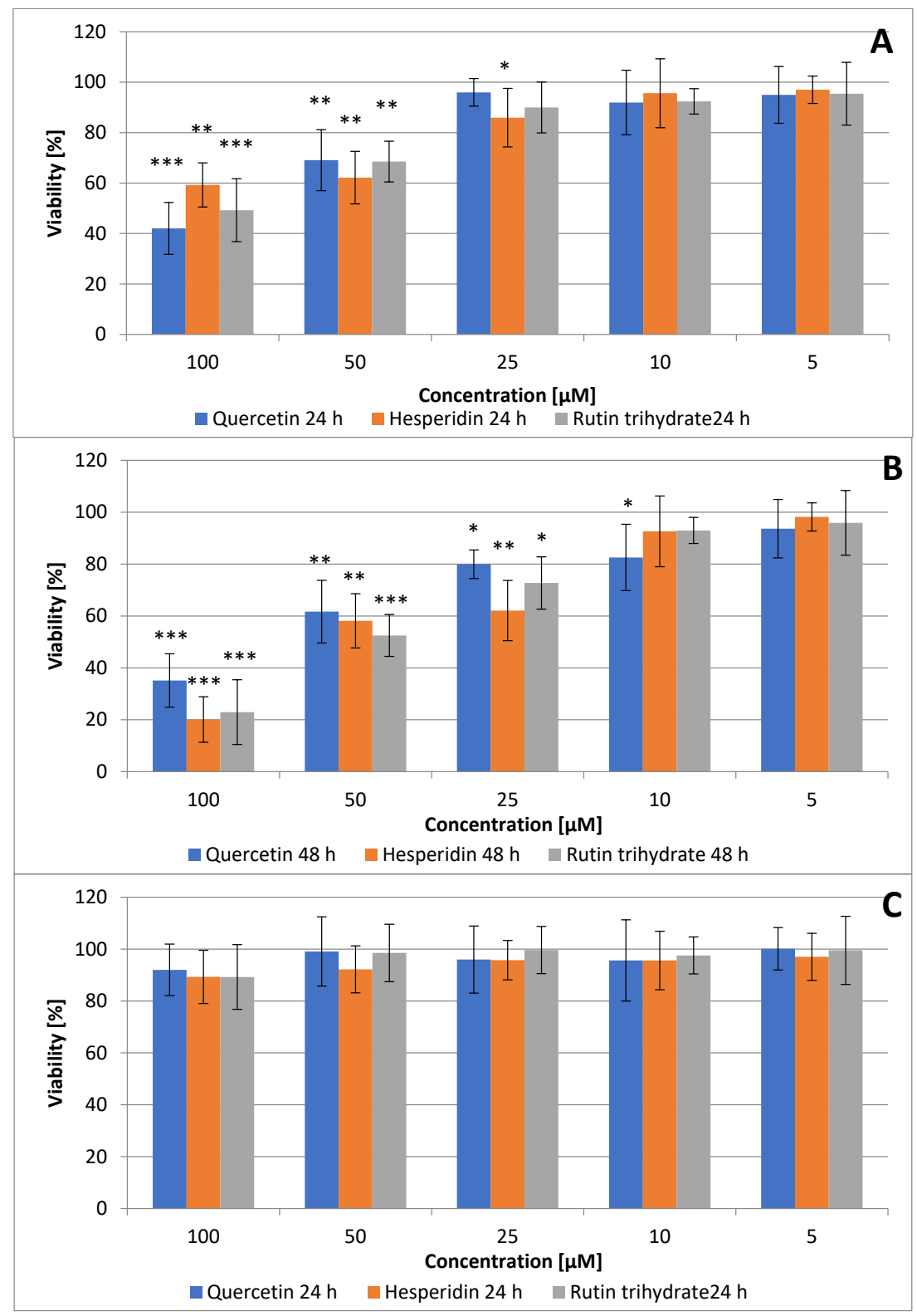

Figure 1. Cont. 


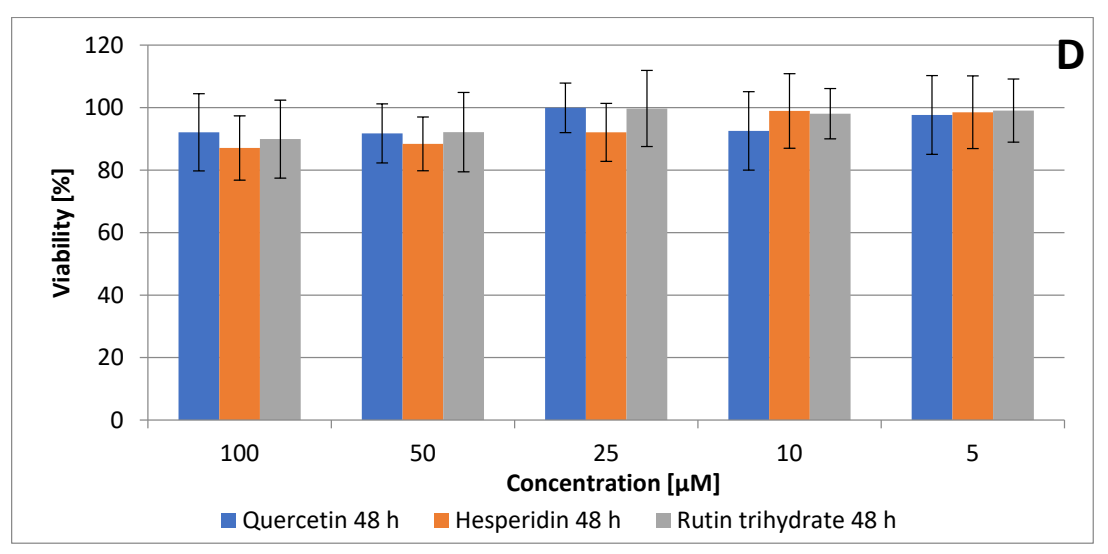

Figure 1. The pharynx squamous carcinoma Detroit 562 (A,B) and normal human dermal fibroblasts (NHDF) (C,D) cell viability analyzed by MTT (3-[4,5-dimethylthiazol-2-yl]-2,5-diphenylotetrazolium bromide) assay. Cytotoxic, dose- and time-dependent effects of Que, Hes, and Rut at flavonoids concentrations above $25 \mu \mathrm{M}$ after $24 \mathrm{~h}(\mathrm{~A})$ and $48 \mathrm{~h}$ (B) of incubation. MTT did not show a major impact of Que, Hes, and Rut below $25 \mu \mathrm{M}$ on Detroit 562 cells viability rate. In the contrary, no major effect was observed for NHDF cells exposed to flavonoids after 24 hours (C) and 48 hours (D). The results were presented as the mean and standard deviation of three independent experiments, each using 12 wells. ${ }^{*} p<0.05,{ }^{* *} p<0.01,{ }^{* * *} p<0.001$; ANOVA Friedman ANOVA test, Wilcoxon test).

Based on the presented data, as confirmed by the extrapolated inhibitory concentration value, $50 \%$ of the mortality of Detroit 562 cells was observed after $48 \mathrm{~h}$ of incubation, with an $\mathrm{IC}_{50}$ of $58.83 \mu \mathrm{M}, 60.53 \mu \mathrm{M}$ and $73.23 \mu \mathrm{M}$, for Hes, Rut and Que, respectively (Table 1). Accordingly, two doses (50 and $100 \mu \mathrm{M})$ were selected for further apoptosis assessment (Supplementary Materials).

Table 1. The $\mathrm{IC}_{50}$ values of selected polyphenols relative to the Detroit 562 cell line.

\begin{tabular}{ccc}
\hline & IC $_{\mathbf{5 0}}[\boldsymbol{\mu M}]$ \\
& $\mathbf{2 4} \mathbf{~ h}$ & $\mathbf{4 8 ~ h}$ \\
\hline Quercetin & 87.30 & 73.23 \\
Hesperidin & 108.25 & 58.83 \\
Rutin & 95.94 & 60.53 \\
\hline
\end{tabular}

\subsection{Hesperidin and Rutin Stimulate Cell Apoptosis and Necrosis, while Quercetin Induces Primarily Necrosis in Detroit 562 Cells}

The Detroit 562 cells were stained with V-FITC-linked annexin after exposure to Que, Hes, and Rut, and then analyzed using flow cytometry to determine the percentage of apoptotic cells. The number of total apoptotic Detroit 562 cells vastly increased following exposure to concentrations of $100 \mu \mathrm{M}$ vs. $50 \mu \mathrm{M}$ and after $48 \mathrm{~h}$ (Figure 2 and Figure S1), with the most noticeable results obtained for Hes. Specifically, the difference between concentrations of $50 \mu \mathrm{M}$ and $100 \mu \mathrm{M}$ in the percentage of live and late apoptotic cells was apparent after incubation of $48 \mathrm{~h}$. Compared with the untreated control, there was a significant increase in cell phenotypes of apoptotic cells Annexin+/7-AAD+ and Annexin $+/ 7$-AAD- in a dose-dependent manner. The use of hesperidin, both at 50 and $100 \mu \mathrm{M}$, resulted in a statistically significant decrease in cell phenotype Annexin -/7-AAD- and cell phenotypes Annexin +/7-AAD-, Annexin +/7-AAD+ and Annexin -/7-AAD+ after $24 \mathrm{~h}$ of incubation. Consequently, the most noticeable change in the number of cells having an apoptotic cell phenotype was observed using a $100 \mu \mathrm{M}$ concentration of Hes and $48 \mathrm{~h}$ of incubation (Figure 2A, Figure S1). The particularly significant changes were observed in the number of dead or late apoptotic cells, confirming that the cells entered the execution phase of the apoptotic process. Results demonstrated no time-related effect for Hes at a 
concentration of $50 \mu \mathrm{M}$, although the obvious effect was observed using hesperidin at a double concentration of $100 \mu \mathrm{M}$ (Figure 2A).

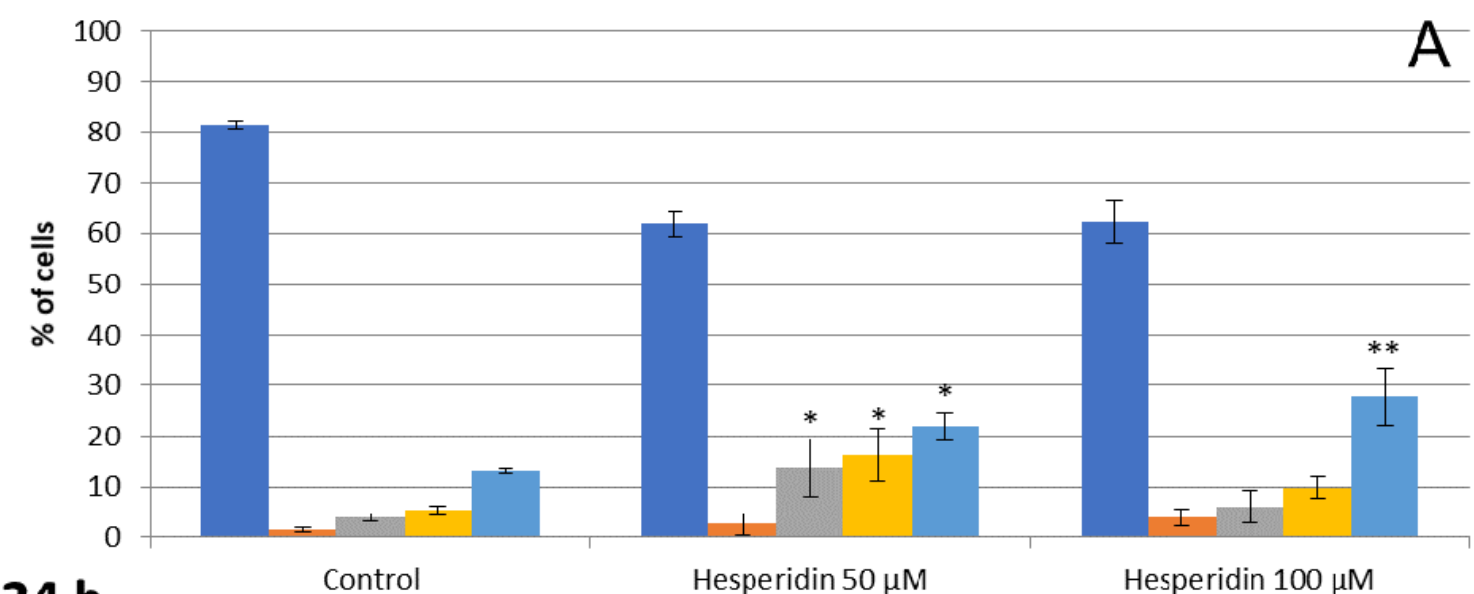

$24 \mathrm{~h}$

$$
\text { Control }
$$

Hesperidin $50 \mu \mathrm{M}$

Hesperidin $100 \mu \mathrm{M}$

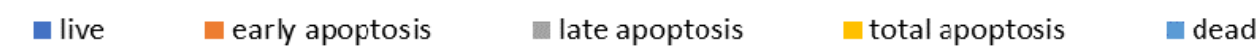

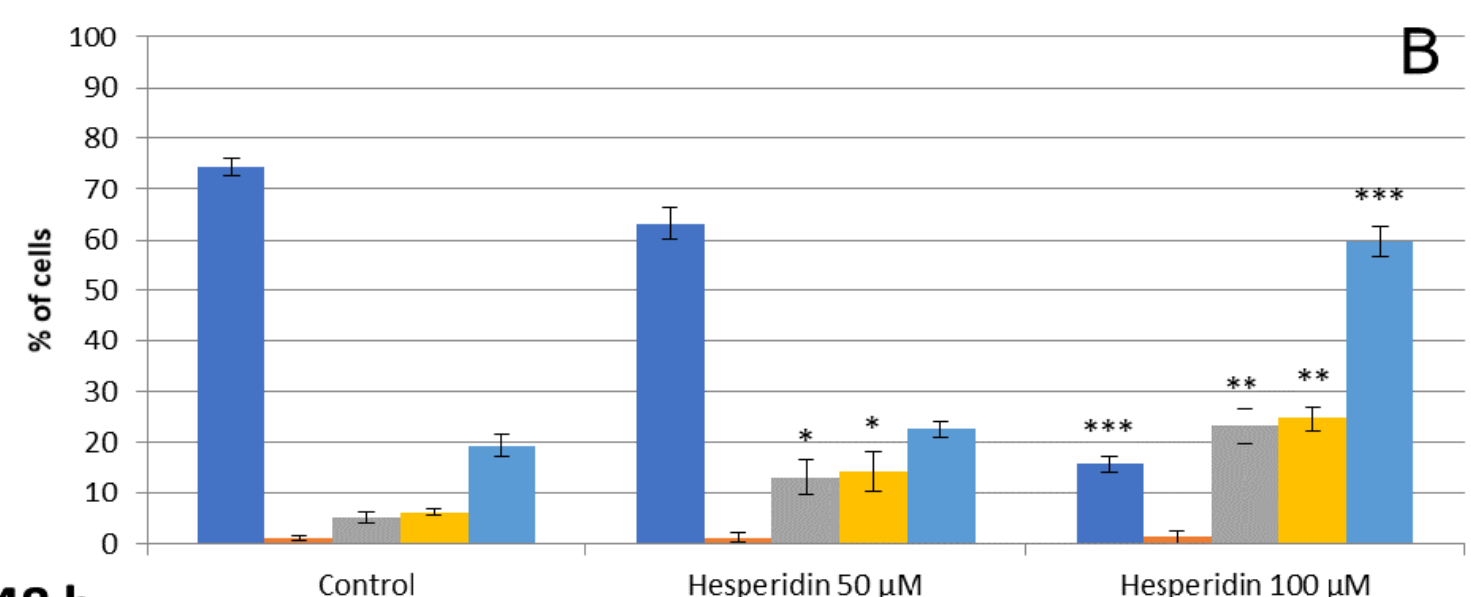

$48 \mathrm{~h}$

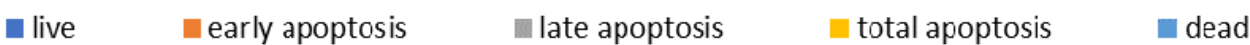

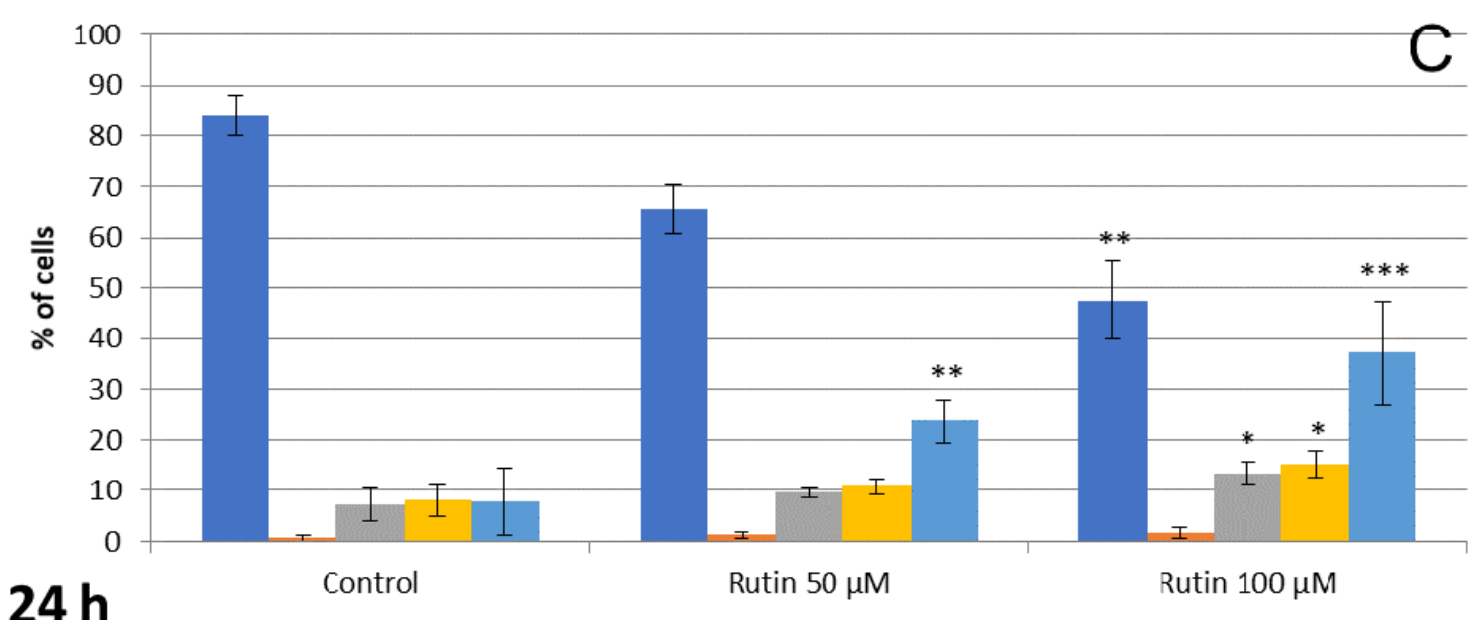

$24 \mathrm{~h}$

- live early apoptosis

late apoptosis

total apoptosis

dead

Figure 2. Cont. 


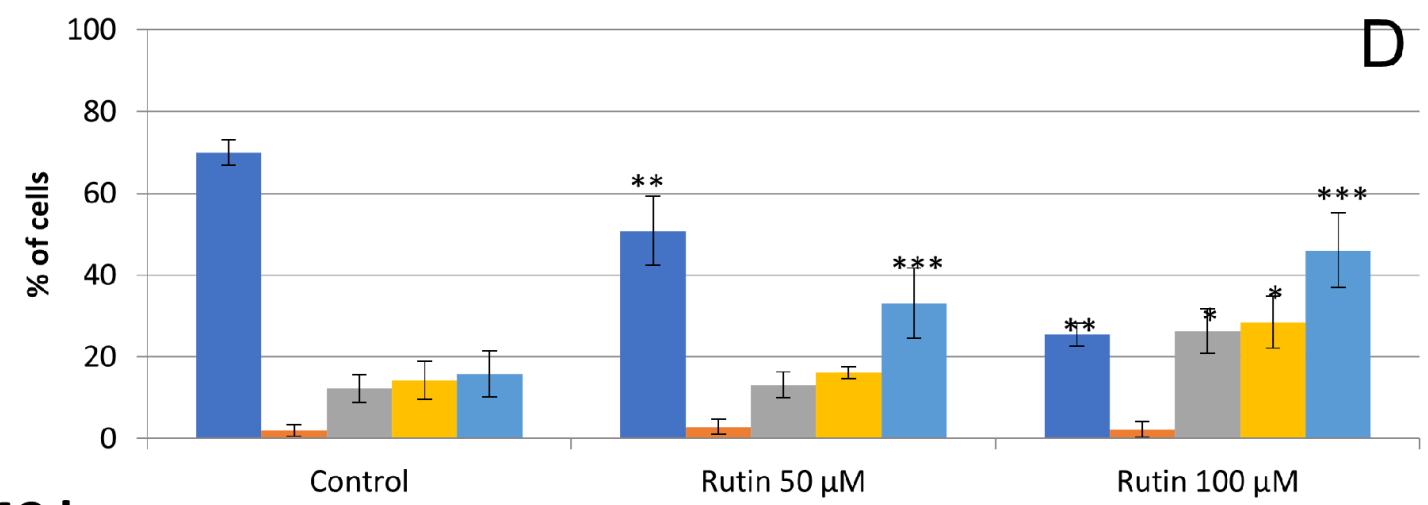

$48 \mathrm{~h}$

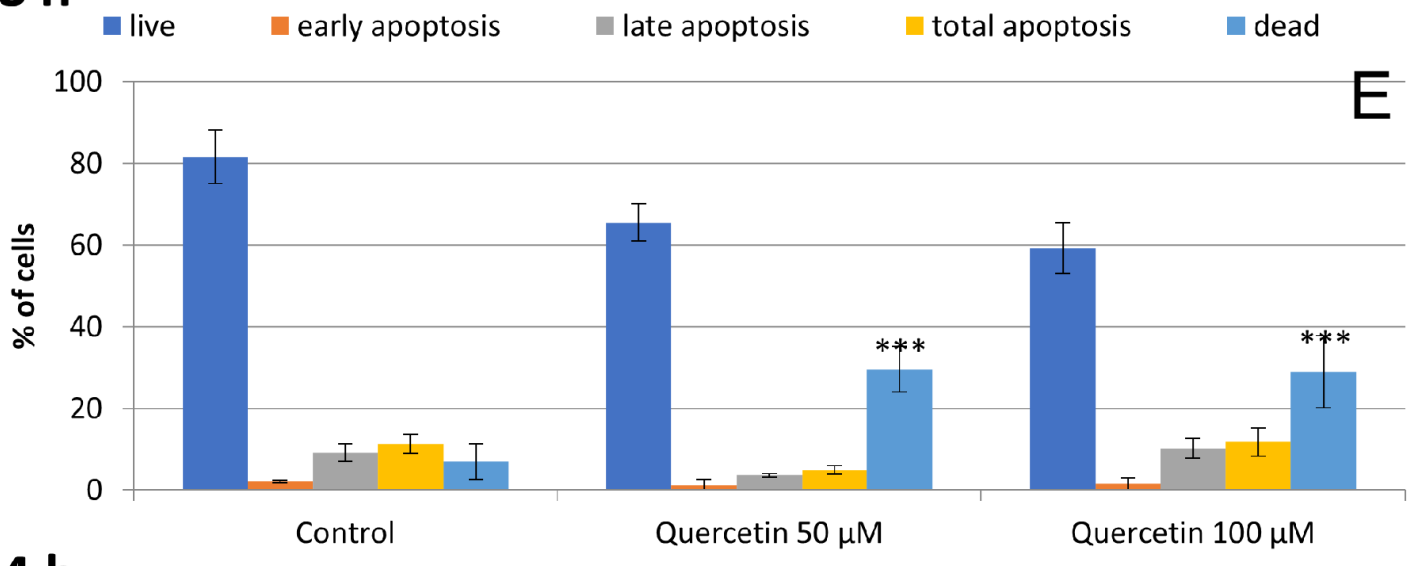

$24 \mathrm{~h}$

- live $\quad$ early apoptosis $\quad$ late apoptosis $\quad$ total apoptosis dead

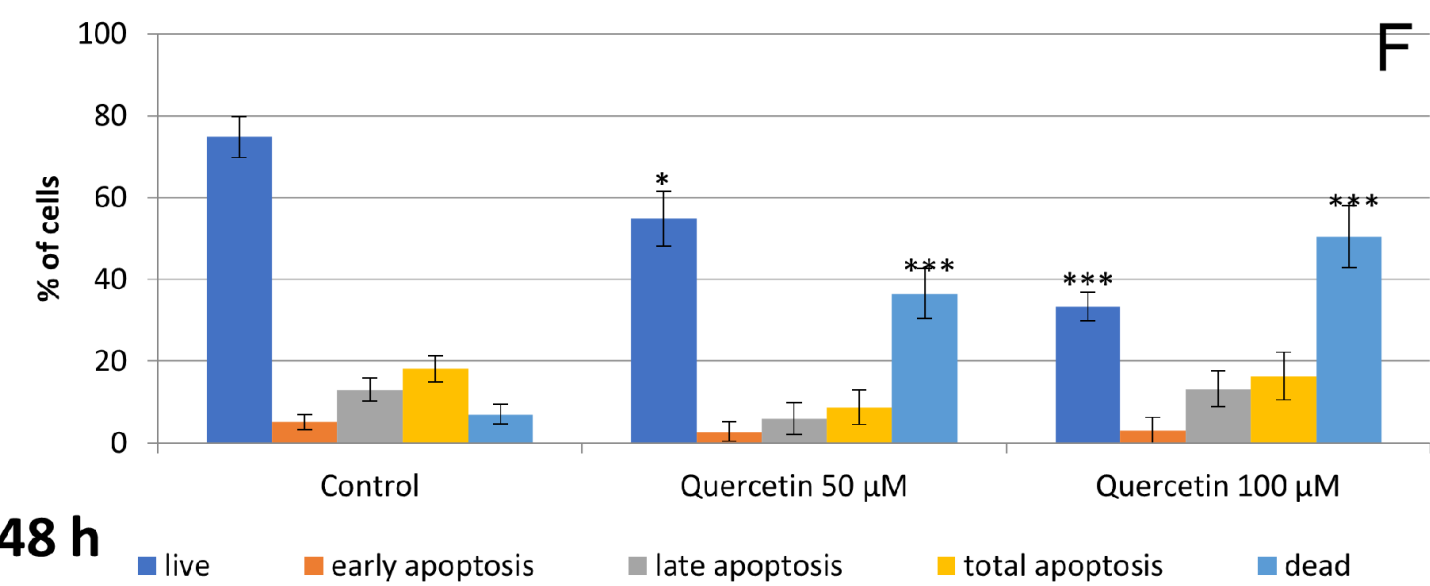

Figure 2. Flow cytometric analysis results. A significant increase in the proportion of total dead Detroit 562 cells following $48 \mathrm{~h}(\mathbf{B}, \mathbf{D}, \mathbf{F})$ vs. $24 \mathrm{~h}(\mathbf{A}, \mathbf{C}, \mathbf{E})$ of exposure to Hes, Rut, Que of 50 and $100 \mu \mathrm{M}$ concentration, compared to the control $\left({ }^{*} p<0.05,{ }^{* *} p<0.01\right.$ and $\left.{ }^{* *} p<0.001\right)$. Vertical bars represent the standard deviations of the means (SD, $n=3$ experiments).

Similar, distinctive changes were observed following $24 \mathrm{~h}$ incubation of the 562 Detroit cells with rutin (Figure 2A,B). The percentage of live cells decreased in comparison to the control group. Marked changes were observed at higher concentrations, which confirmed the impact of dose on achieved result. Subsequently, following $48 \mathrm{~h}$ of incubation of the cells with rutin at $100 \mu \mathrm{M}$, there was a statistically significant increase in the cell phenotype Annexin +/7-AAD+, confirming that the cells treated with Rut died by apoptosis. It also showed a clear time-related effect of the proapoptotic activity of Rut in both analyzed concentrations. 
Quercetin applied in two concentrations of 50 and $100 \mu \mathrm{M}$ did not significantly increase the percentage of cells with phenotypes Annexin +/7-AAD- and Annexin +/7-AAD+ after both the 24 and $48 \mathrm{~h}$ incubation periods ( $p>0.05$, Figure $2 \mathrm{~B}$ ). On the contrary, a significant elevation of necrotic cells was observed, suggesting the direct cytotoxic activity of Que.

\subsection{The Effects of Hesperidin, Rutin and Quercetin on Detroit 562 HNSCC Cells Detected Microscopically}

The microscopic assessment demonstrated numerous changes in the examined HNSCC carcinoma cells, including fewer vital cells (shown in Figure 3), resulting in cell shrinkage and cytoplasmic condensation, following the $48 \mathrm{~h}$ of incubation with Hes, Que and Rut. Moreover, the cells' detachment, reduced cell-cell contact and their structure/shapes were also observed. Detroit 562 cells with $100 \mu \mathrm{M}$ of Rut, Que and Hes clearly revealed necrotic, and a diminished number of, HNSCC carcinoma cells in suspension, cytoplasmic shrinkage, and stained fragments of decomposed cancer cells. Detroit 562 cells with $50 \mu \mathrm{M}$ of Rut and Que revealed a distinctive decreased of cells' number without a significant nucleus and cytoplasmic changes. Detroit 562 cells with $50 \mu \mathrm{M}$ of Hes demonstrated less obvious morphological and/or quantitative changes related to number of cells and chromatin condensation. These observations reinforce the zero hypothesis that the exposure to flavonoids may hypothetically reduce HNSCC cancer cells' growth compared to the control.
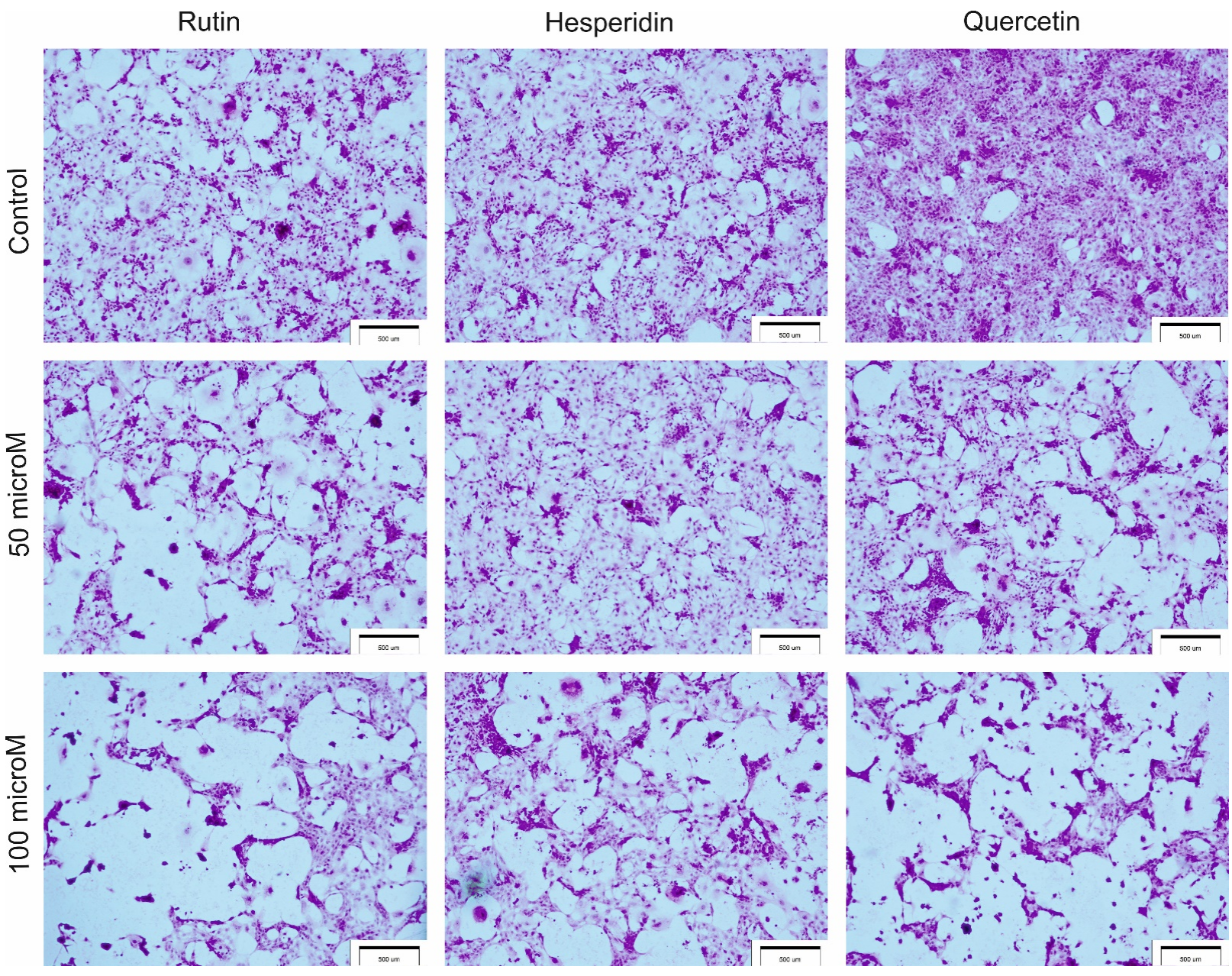

Figure 3. Cells number and cytomorphological features of Detroit 562 cells treated with Rut, Que and Hes in concentrations of $50 \mu \mathrm{M}$ and $100 \mu \mathrm{M}$ after $48 \mathrm{~h}$ of exposure (optical magnification $=\times 40$ ). Detroit 562 cells grown as a control with DMSO solvent showed the characteristic monolayer of head and neck squamous cell carcinoma (HNSCC) cells with cellular atypia's common characteristics: nuclear and cytoplasmic pleomorphism, increased nucleus vs. cytoplasm ratio, irregularly shaped cells, and hyperchromasia. 


\subsection{Reduction of Detroit 562 SCC Cancer Cells Migration Rate}

The results of the wound healing assay are presented in Figure 4 for non-preincubated Detroit 562 cells and in Figure 5 for cells pre-incubated with flavonoids, compared to the control, where the cell migration rate was almost completed, achieving a value of $6 \%$ vs. $3 \%$ of the remaining original "open wound" after $24 \mathrm{~h}$. For pre-incubated cells with flavonoids, the arrest of the wound's closure was apparent, reaching a rate value of $77 \%$ still opened wound after $12 \mathrm{~h}$ for Que and Hes (Figure 5). On the contrary, the wound was almost completely closed after $24 \mathrm{~h}$ (control). Using a $\frac{1}{4} \mathrm{IC}_{50}$ dose of tested flavonoids, the Detroit 562 cells' motility was inhibited in a different manner, with a predominant efficacy of Hes and Que. After $12 \mathrm{~h}$ and $24 \mathrm{~h}$ for non-preincubated cells (Figure 4), the opened wound area was almost intact for Que and decreased to $50 \%$ Hes vs. $55 \%$ Rut and $44 \%$ Hes vs. $38 \%$ Rut, respectively. The wound closure inhibition was obvious following the Hes, Que and Rut treatment. Interestingly, for rutin, the wound area value was $22 \%$ compared to the original scratch after $24 \mathrm{~h}$ (Figure 5). Subsequently, a value of $59 \%$ was achieved after $6 \mathrm{~h}$ and $35 \%$ after $12 \mathrm{~h}$. Inhibition of cells' migration showed a time-dependent trend. All three flavonoids, Hes, Que and Rut, arrested the Detroit 562 migration ability in a different magnitude, with the most apparent effect noticed for Hes and Que and, as a result, the 'wound area' was impenetrable by the cancer cells.
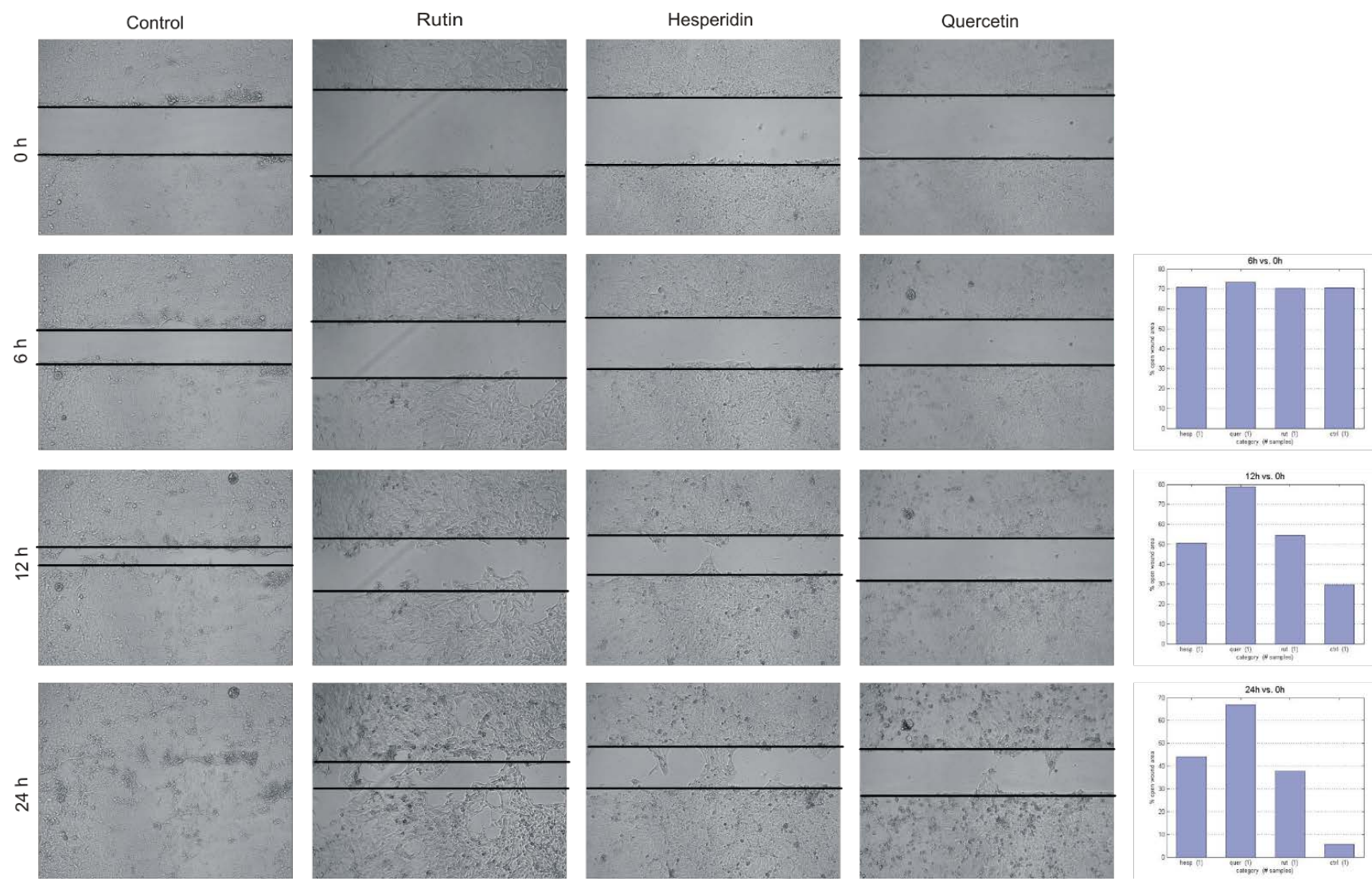

Figure 4. Quercetin and Hesperidin at concentrations of $1 / 4 \mathrm{IC}_{50}$ promoted Detroit SCC 562 cells' migration effect, with an apparent time-dependent mode. After $24 \mathrm{~h}$, the gap did not reach full closure for all tested agents. Que revealed considerably greater effect on Detroit 562 cell migration inhibition compared to Hes and Rut. Hes treatment for $12 \mathrm{~h}$ and a dose of $1 / 4 \mathrm{IC}_{50}$ demonstrated that the wound area remained almost unchanged over time. The cell migration factor was performed quantitatively by monolayer gap closure migration assay, and also quantitatively, validated by dedicated ImageJ software. The results are presented as the 'open gap area' in relation to the initial scratch volume, after $6 \mathrm{~h}, 12 \mathrm{~h}$, and $24 \mathrm{~h}$ of experiment. 

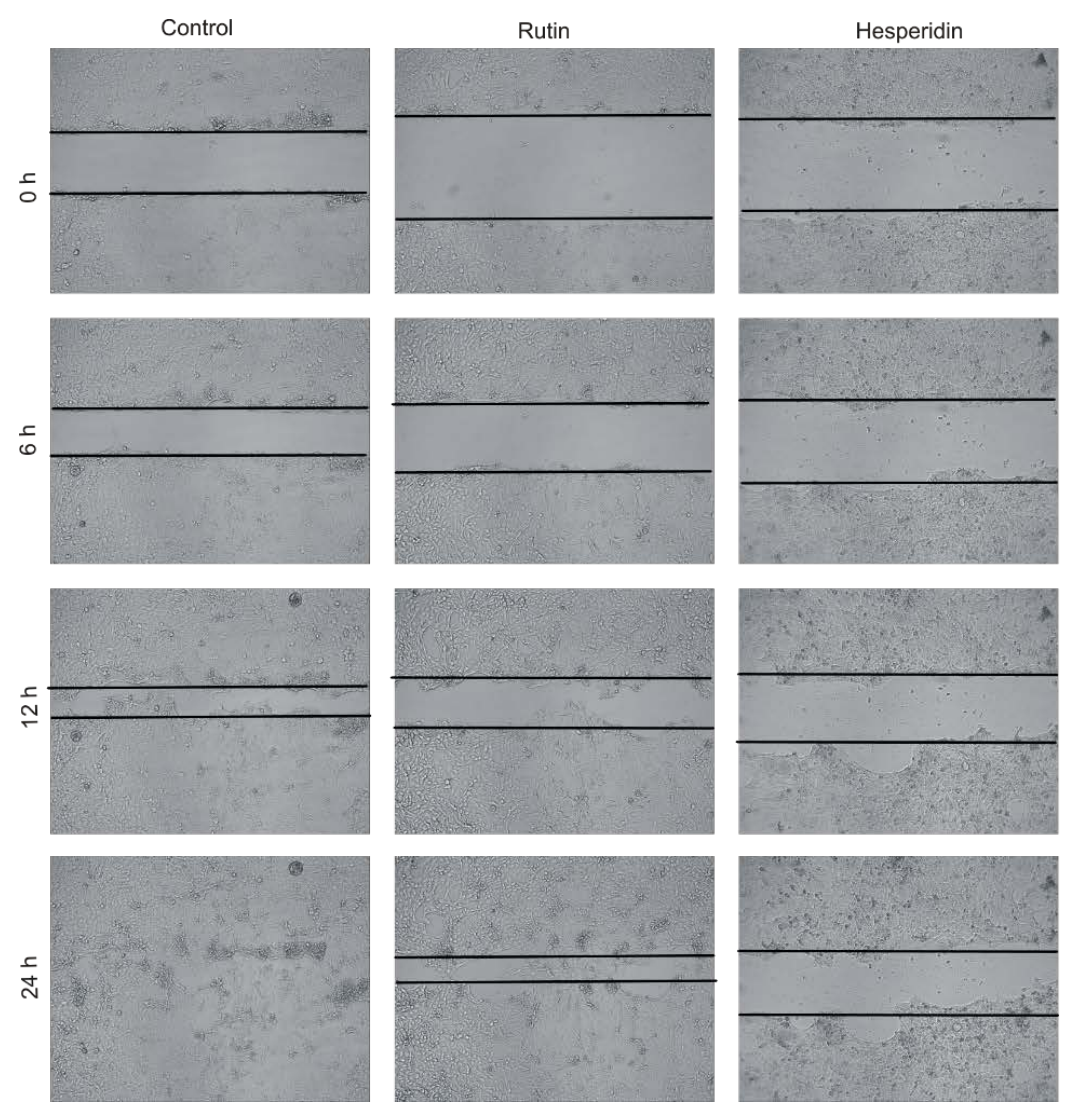
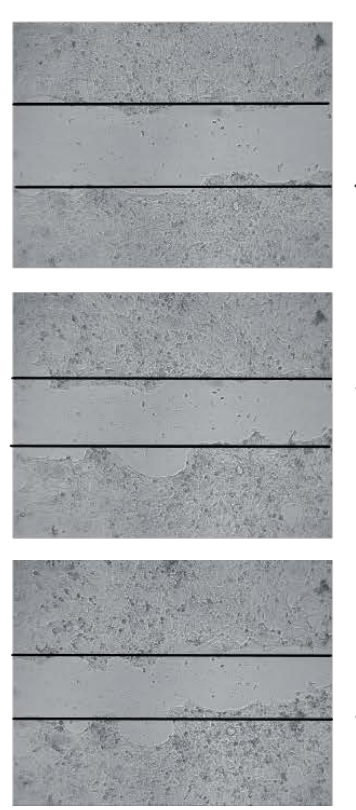
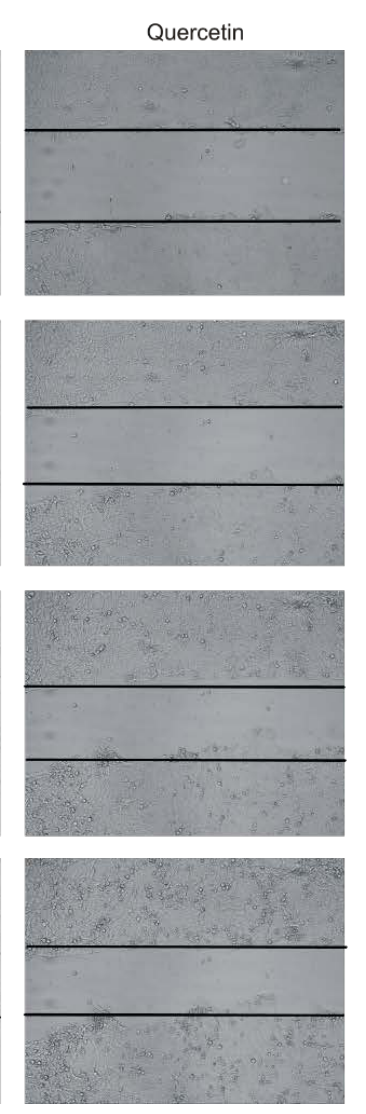
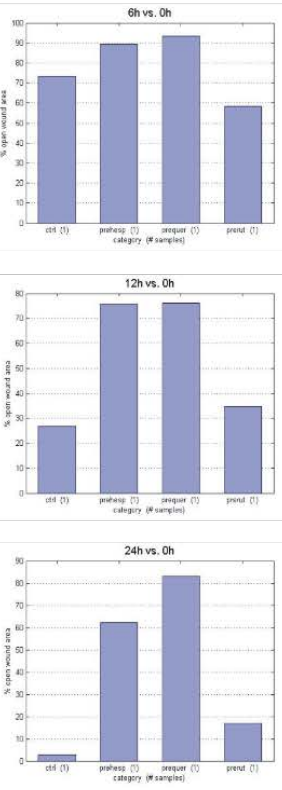

Figure 5. Pre-incubated Detroit 562 cells with flavonoids. Results of wound healing assay revealed arrest assay and preincubated Detroit 562 cells were similar compared to a standard experiment. Quercetin and Hesperidin at concentrations of 1/4 IC 50 inhibited Detroit SCC 562 cells' migration as after $24 \mathrm{~h}$ the gap/wound was still apparent, compared to control. Hesperidin revealed lesser effect on Detroit 562 cell migration inhibition compared to Que. Que and Hes treatment for $12 \mathrm{~h}$ and a dose of $1 / 4 \mathrm{IC}_{50}$ demonstrated that the wound area remained almost unchanged over time.

\section{Discussion}

Due to the lack of comprehensive in vitro studies on the compared actions of various flavonoids, the hypothesis was set up that commonly occurred compounds, i.e., hesperidin, rutin and quercetin, affect the viability and migration of Detroit 562 primary pharynx cancer cells. Accordingly, our results support that rutin, quercetin and hesperidin can be potentially used in therapy against HNSCC, either alone or in combination with other flavonoids and/or chemotherapeutic drugs, in the context of the adjunct therapeutic protocol. Hence, the innovative methods of controlling the biological phenolic compounds' effects have a new way of practical application in oncology. In this study, all three compounds exhibited apoptotic characteristics at different magnitudes after treating Detroit 562 cells for 24 and $48 \mathrm{~h}$, whereas the most prominent cytotoxic and apoptotic effects were detected for rutin and hesperidin. Surprisingly, compared to the other studies on human cancer cells, the least evident activity was caused by quercetin. The addition of these natural compounds may produce a suppressive effect and could be potentially used as a adjuvant chemotherapy, with a protective effect towards normal cells. Nevertheless, the exact mechanism of flavonoid action is not fully understood.

Complex pharmacological properties and the pharmacokinetics of flavonoids provide the rational basis for their potential application in head and neck oncology as already reported for chemoprevention and/or adjuvant therapy in other cancers. There is currently an increasing interest in the clinical application of flavonoids, which leads to further clinical trials and the discovery of new flavonoids derivatives with bioactive properties. Various intracellular mechanisms are associated with anti-tumor effects, particularly taking into 
consideration squamous cell carcinoma cells' viability. Flavonoid reactivity based on their structure enables them to act as antioxidant agents, modulating the intercellular signaling pathway and metabolism, which results in an overall anti-proliferative response, apoptosis and cell cycle arrest $[15,16,18-21,23,26,30,32-36]$. Furthermore, the accumulating evidence confirms that flavonoids modulate the cytochrome P450 and ATP-binding cassette (ABC) protein families, contributing to their antiproliferative effect, as well as anti-multi-drug resistance activity $[37,38]$.

With reference to head and neck squamous cell carcinoma, one of the most studied flavonoid compounds is quercetin, a naturally occurring polyphenol present in cranberries, blueberries, apples, red wine, onions and the flowers of hawthorn and horse chestnut, and that is why much of it is also in bee propolis. The broad spectrum of quercetin bio pharmacological properties indicates its potential clinical application in chemoprevention and chemotherapy due to its proven antioxidant properties. Quercetin has shown anticancer capabilities for liver, breast, colon, bladder, prostate, oral and nasopharyngeal carcinomas; although, it has not yet been clinically approved $[6,10,13,15,18,24-26,39-43]$. Chen et al. [39] observed the dose-dependent cytotoxic effect of quercetin $(50 \mu \mathrm{M})$ in the tongue cancer cell line SCC25 with an increased percentage of Annexin V-positive cells by approximately $15 \%$. This does not agree with our experiment as we did not identify statistically significant changes in the number of apoptotic cells after exposure to quercetin at similar concentration. However, the $\mathrm{IC}_{50}$ value for quercetin obtained in our study is consistent with their results. Correspondingly, Haghiac and Walle [26] demonstrated that quercetin induces a stress response, SCC-9 S-phase inhibition and necrosis at $24 \mathrm{~h}$ and $48 \mathrm{~h}$, whereas at $72 \mathrm{~h}$ SCC-9 cells underwent apoptosis mediated hypothetically by the inhibition of thymidylate synthase protein and associated with the activation of caspase-3 in a time- and dose-dependent manner. Quercetin significantly induces apoptosis and inhibits proliferation, angiogenesis and metastasis in vitro, while, in vivo, it is effective in inhibiting the growth of xenograft tumor models. In rat models, it was observed that quercetin increased level of antioxidant enzymes, superoxide dismutase (SOD), catalase (CAT), and apoptotic proteins (Bax), as well as decreased insulin-like growth factor receptor 1 (IGFIR), protein kinase $\mathrm{B}(\mathrm{AKT})$, androgen receptor (AR), epidermal growth factor receptor (EGFR), the phosphatidylinositol 3-kinase/protein kinase B (PI3K/AKT) signaling pathway and cell adhesion molecules. Despite the growing preclinical evidence on the role of this molecule in terms of chemoprevention and as adjuvant to chemotherapeutics, the clinical evidence is still scanty $[44,45]$. On the contrary, the results obtained by Kandaswami et al. [23] who examined the effects of four plant flavonoids (quercetin, taxifolin, nobiletin and tangeretin) on the in vitro growth of a human primary pharynx squamous cell carcinoma cell line (HTB43) elucidated no inhibition of SCC cancer cell growth caused by quercetin and taxifolin at any of the concentrations tested. However, the other polymethoxylated flavonoid, nobiletin and tangeretin, exhibited a significant reduction of HTB43 cells' growth.

The in vitro study results carried out by Khan et al. [40] showed a more significant activation of the apoptosis of colon cancer cells HCT-116 compared to our results and proliferation inhibition caused by quercetin, as well as its derivative 5,30-dihydroxy-3,7,40triethoxyflavone (TEF). This was demonstrated by fragmented cell nuclei, reduction in the mitochondrial membrane potential and an increase in reactive oxygen species (ROS). The TEF treatment also increased levels of proapoptotic factors and reduced the levels of anti-apoptotic proteins of the BCL2 family. TEF led to the activation of mitochondrial c-Jun N-terminal kinases, which play a key role in the initiation of oxidative stress and the activation of apoptotic cell death via the caspase-dependent pathway. Moreover, a study conducted by Su et al. [46] demonstrated that quercetin increases the number of bladder cancer cells (MB49, T24, UMUC3) Annexin V (+) phenotype, with a dose-dependent trend. However, the authors concluded that quercetin at doses below $100 \mu \mathrm{M}$ is not a strong activator of apoptosis and they observed no significant changes in the number of apoptotic cells at a concentration $40 \mu \mathrm{M}$, which was also confirmed by our results. 
Baruah et al. [42] elucidated that quercetin at ultra-low concentrations inhibited the viability and proliferation of prostate cancer cell line PC-3, equally increasing the percentage of apoptotic cells, an increased number of cells in the G2/M phase, and a decrease of cells in the G0/G1 phase. Thus, quercetin affected all cancer cell cycle phases, stopping cell progression and proliferation and ultimately increasing the degree of apoptosis in the cell population. Furthermore, quercetin in concentrations of 20 and $25 \mu \mathrm{M}$ significantly induced caspase 3 activity after $24 \mathrm{~h}$ of treatment, indicating the induction of apoptosis by quercetin. According to Lim et al. [43], quercetin has a potential therapeutic agent's biological characteristics against choriocarcinoma (JAR and JEG3) cells, because quercetin stimulates choriocarcinoma cells to programmed cell death. The IC values for the JAR cell line amounted to about $10 \mu \mathrm{M}$ and were well above $100 \mu \mathrm{M}$ for JEG3. The authors observed an obvious increase in the cell phenotype Annexin V (-)/PI (+).

Hesperidin, a flavanone present in citrus fruit, has been identified as a potent anticancer agent due to its proapoptotic and antiproliferative effects on tumor cells. Available studies elucidated the hesperidin-activated apoptosis induction, confirming that hesperidin has an inhibitory effect on growth in a dose-dependent manner. The combination of hesperidin and doxorubicin unexpectedly increased breast cancer MCF7/Dox's survival, suggesting the antagonistic action of these compounds in conjunction [46]. Despite this, all analyzed concentrations of hesperidin activated apoptosis in MCF-7, capable of activating programmed cancer cell death. Compared to our $\mathrm{IC}_{50}$ values, several factors might contribute to discrepant results between the cytotoxic response of different cancers cells to flavonoids. Molecular differences and various heterogeneous gene expression patterns could explain the marked discrepancy in the cytotoxic effect of phenolic compounds.

Banjerdpongchai et al. [47] showed that the cytotoxic effects of the three analyzed flavonoids concerning hepatocellular carcinoma cell line HepG2 were dose-dependent, stating that hesperidin has cytotoxic activity towards the human hepatoma HepG2. Like previous studies, hesperidin increased the percentage of early apoptotic cells (Annexin V staining) from $5 \%$ to $22.3 \%$ with a concentration corresponding to the $\mathrm{IC}_{50}$ value. This was also confirmed in our experiment after Detroit 562 cells were incubated with hesperidin for $48 \mathrm{~h}$. Besides, the sensitivity grading of human HepG2 cells for flavonoids was as follows: hesperidin $>$ naringin $>$ neohesperidin $>$ naringenin. The antiproliferative and proapoptotic efficacy of hesperidin was also demonstrated by Birsu Cincin et al. [48] towards non-small cell lung cancer lines A549 and NCI-H358, as a 1.19-fold increase in caspase-3 activity was shown after $48 \mathrm{~h}$ of incubation with $50 \mu \mathrm{M}$ of hesperidin in the A549 cells compared to the untreated control cells. These results indicate that dose-dependent hesperidin-induced apoptosis may be related to the activity of caspase-3, and hesperidin significantly increased the number of early apoptotic cells in both non-small cell lung cancer lines.

In general, considering other types of cancer, hesperidin induces apoptosis of HeLa cells (increased condensation and nuclear DNA fragmentation) and inhibits the proliferation of HeLa cells and their cell cycle as confirmed by the experiment of Wang et al. [20]. According to these results, hesperidin also promoted the generation of ROS, the mobilization of intracellular $\mathrm{Ca}^{2+}$, the loss of mitochondrial membrane potential, increased release of cytochrome $C$ and the elevation of GADD153/CHOP and GRP78, related to the caspase-dependent apoptosis pathway. This has also been demonstrated in cell cycle arrest in the G0/G1 phase and reduced expression of cyclinD1, cyclinE1, and cyclin-dependent kinases.

Numerous studies have shown that rutin-widely consumed in the diet in the form of fruit, vegetables, and beverages, such as tea and wine-prevents hypertension and exerts anti-inflammatory and has antioxidant properties. Santos et al. [49] elucidated that rutin $(50-100 \mu \mathrm{M})$ reduces the proliferation and viability of the highly proliferative human glioblastoma GL-15 cells, also diminishing the level of P-ERK1/2 and accumulation of cancer cells in the G2 phase of the cell cycle. Additionally, the GL-15 cells exposed to $100 \mu \mathrm{M}$ rutin underwent apoptosis as confirmed by flow cytometry. This proapoptotic trend has been replicated in our study. The researchers suggested that rutin, due to its 
ability to induce cell differentiation and the induction of apoptosis, can be considered a potential candidate for the treatment of malignant gliomas. These data coincide with our results, showing that rutin's use initiated the activation of apoptosis in Detroit 562 cells. It is worth noting that $20 \mu \mathrm{M}$ and $50 \mu \mathrm{M}$ rutin can reverse multidrug resistance and restore chemosensitivity to cyclophosphamide and methotrexate of human chemoresistant, triple-negative breast cancer cells MB-MDA-231 [6].

Collectively, the herein presented data clearly support the hypothesis that naturally occurring phenolic compounds may exhibit potential for application in adjuvant cancer treatment. They may play a supporting role in reduced chemoresistance of cancer cells, debilitating the limitations of standard chemotherapeutic regimens. Their cumulative action, also combined with standard chemotherapy and radiotherapy, could benefit patients with some forms of squamous cell carcinoma.

\section{Conclusions}

Our comparative study has confirmed the hypothesis that exposure to bioactive flavonoids quercetin, hesperidin and rutin has dose- and time-dependent effects on selected head and neck cancer cells, causing the arrest of cancer cells' migration and initiating the apoptosis pathway in Detroit 562 squamous carcinoma cells. These natural substances affect the vitality and motility of cancer cells originating from the head and neck region and induce programmed cell death, although their cytotoxicity appears to be variable, depending on their concentrations and, hypothetically, their mode of biological action.

Supplementary Materials: The following are available online at https://www.mdpi.com/2227-9 $717 / 9 / 3 / 426 / \mathrm{s} 1$, Figure S1. Induction of Detroit 562 cell apoptosis resulted from $24 \mathrm{~h}$ and $48 \mathrm{~h}$ exposure to quercetin, hesperidin and rutin $(\mathbf{A}, \mathbf{B})$, as-sessed by flow cytometry. Early apoptotic Detroit 562 HNSCC cells are presented in scatter plot's lower-right quadrant, and live cells are in the lower-left quadrant. Representative scatter plots obtained via flow cytometry of cells stained with annexin V, and 7-AAD illustrate the distinct distribution of viable/living Detroit 562 cells (lower left quadrant), cells with early apop-tosis (lower right quadrant), late-stage apoptosis or necrotic/dead cells (upper right quadrant) and cells undergoing necrosis (the upper left quadrant). The cell death percentage fraction was obtained from the corresponding diagrams for the tested concentrations vs the control late apoptosis. All compounds induced necrosis or late apoptosis in a dose-dependent manner as measured by the Muse ${ }^{\mathrm{TM}}$ Annexin V and Dead Cell assay in the tumour cells Detroit 562, which was confirmed by marked decreased of a percentage of live cells.

Author Contributions: Conceptualization, A.D. and R.K.; formal analysis, R.K.; investigation, R.K.; methodology, R.K.; project administration, A.D.; resources, A.D.; supervision, R.D.W.; validation, A.D., R.K. and R.D.W.; visualization, R.K.; writing—original draft, A.D. and R.K.; writing-review \& editing, A.D., R.K., M.T., E.M.V. and M.I. All authors have read and agreed to the published version of the manuscript.

Funding: The study was supported by an individual grant of Ministry of Science and High Education, Medical University of Silesia, KNW-1-142/K/7/K, SUM and KNW-2-102/N/9/N, Katowice, Poland.

Institutional Review Board Statement: Not applicable.

Informed Consent Statement: Not applicable.

Data Availability Statement: Data available on request.

Conflicts of Interest: The authors declare no conflict of interest.

\section{References}

1. Smittenaar, C.R.; Petersen, K.A.; Stewart, K.; Moitt, N. Cancer incidence and mortality projections in the UK until 2035. Br. J. Cancer 2016, 115, 1147-1155. [CrossRef]

2. International Agency for Research on Cancer. GLOBOCAN 2012: Estimated Cancer Incidence, Mortality and Prevalence Worldwide in 2012; World Health Organization: Lyon, France, 2012.

3. Marur, S.; Forastiere, A.A. Head and neck cancer: Changing epidemiology, diagnosis, and treatment. Mayo. Clin. Proc. 2008, 83, 489-501. [CrossRef] [PubMed] 
4. $\quad$ Rieke, D.T.; Klinghammer, K.; Keilholz, U. Targeted Therapy of Head and Neck Cancer. Oncol. Res. Treat 2016, 39, 780-786. [CrossRef]

5. Amin, A.R.; Kucuk, O.; Khuri, F.R.; Shin, D.M. Perspectives for cancer prevention with natural compounds. J. Clin. Oncol. 2009, 27, 2712-2725. [CrossRef] [PubMed]

6. Iriti, M.; Kubina, R.; Cochis, A.; Sorrentino, R.; Varoni, E.M.; Kabała-Dzik, A.; Azzimonti, B.; Dziedzic, A.; Rimondini, L.; Wojtyczka, R.D. Rutin, a Quercetin Glycoside, Restores Chemosensitivity in Human Breast Cancer Cells. Phytother. Res. 2017, 3, 1529-1538. [CrossRef] [PubMed]

7. Shrotriya, S.; Agarwal, R.; Sclafani, R.A. A perspective on chemoprevention by resveratrol in head and neck squamous cell carcinoma. Adv. Exp. Med. Biol. 2015, 815, 333-348.

8. Gordaliza, M. Natural products as leads to anticancer drugs. Clin. Transl. Oncol. 2007, 9, 767-776. [CrossRef] [PubMed]

9. Wahle, K.W.; Brown, I.; Rotondo, D.; Heys, S.D. Plant phenolics in the prevention and treatment of cancer. Adv. Exp. Med. Biol. 2010, 698, 36-51. [PubMed]

10. Rahman, M.A.; Amin, A.R.; Shin, D.M. Chemopreventive potential of natural compounds in head and neck cancer. Nutr. Cancer 2010, 62, 973-987. [CrossRef]

11. Dunn, B.K.; Umar, A.; Richmond, E. Introduction: Cancer chemoprevention and its context. Semin. Oncol. 2015, 43, 19-21. [CrossRef]

12. Chahar, M.K.; Sharma, N.; Dobhal, M.P.; Joshi, Y.C. Flavonoids: A versatile source of anticancer drugs. Pharmacogn. Rev. 2011, 5, $1-12$.

13. Sak, K. Cytotoxicity of dietary flavonoids on different human cancer types. Pharmacogn. Rev. 2014, 8, 122-146. [CrossRef] [PubMed]

14. George, V.C.; Dellaire, G.; Rupasinghe, H.P.V. Plant flavonoids in cancer chemoprevention: Role in genome stability. J. Nutr. Biochem. 2017, 45, 1-14. [CrossRef]

15. Chou, C.C.; Yang, J.S.; Lu, H.F.; Ip, S.W.; Lo, C.; Wu, C.C.; Lin, J.P.; Tang, N.Y.; Chung, J.G.; Chou, M.J.; et al. Quercetin-mediated cell cycle arrest and apoptosis involving activation of a caspase cascade through the mitochondrial pathway in human breast cancer MCF-7 cells. Arch. Pharm. Res. 2010, 33, 1181-1191. [CrossRef]

16. Hashemzaei, M.; Delarami Far, A.; Yari, A. Anticancer and apoptosis-inducing effects of quercetin in vitro and in vivo. Oncol. Rep. 2017, 38, 819-828. [CrossRef]

17. Niedzwiecki, A.; Roomi, M.W.; Kalinovsky, T.; Rath, M. Anticancer Efficacy of Polyphenols and Their Combinations. Nutrients 2016, 8, 552. [CrossRef]

18. Deng, X.H.; Song, H.Y.; Zhou, Y.F.; Yuan, G.Y.; Zheng, F.J. Effects of quercetin on the proliferation of breast cancer cells and expression of survivin in vitro. Exp. Ther. Med. 2013, 6, 1155-1158. [CrossRef]

19. Ben Sghaier, M.; Pagano, A.; Mousslim, M.; Ammari, Y.; Kovacic, H.; Luis, J. Rutin inhibits proliferation, attenuates superoxide production, and decreases adhesion and migration of human cancerous cells. Biomed. Pharmacother. 2016, 84, 1972-1978. [CrossRef] [PubMed]

20. Wang, Y.; Yu, H.; Zhang, J.; Gao, J.; Ge, X.; Lou, G. Hesperidin inhibits HeLa cell proliferation through apoptosis mediated by endoplasmic reticulum stress pathways and cell cycle arrest. BMC Cancer 2015, 15, 682. [CrossRef] [PubMed]

21. Cirmi, S.; Ferlazzo, N.; Lombardo, G.E.; Maugeri, A.; Calapai, G.; Gangemi, S.; Navarra, M. Chemopreventive Agents and Inhibitors of Cancer Hallmarks: May Citrus Offer New Perspectives? Nutrients 2016, 8, 698. [CrossRef] [PubMed]

22. Xia, R.; Xu, G.; Huang, Y.; Sheng, X.; Xu, X.; Lu, H. Hesperidin suppresses the migration and invasion of non-small cell lung cancer cells by inhibiting the SDF-1/CXCR-4 pathway. Life Sci. 2018, 201, 111-201. [CrossRef]

23. Kandaswami, C.; Perkins, E.; Soloniuk, D.S.; Drzewiecki, G.; Middleton, E., Jr. Antiproliferative effects of citrus flavonoids on a human squamous cell carcinoma in vitro. Cancer Lett. 1991, 56, 147-152. [CrossRef]

24. Dziedzic, A.; Kubina, R.; Kabała-Dzik, A.; Wojtyczka, R.D.; Morawiec, T.; Bułdak, R.J. Caffeic acid reduces the viability and migration rate of oral carcinoma cells SCC-25) exposed to low concentrations of ethanol. Int. J. Mol. Sci. 2014, 7, 18725-18741. [CrossRef]

25. Kuo, Y.Y.; Jim, W.T.; Su, L.C. Caffeic Acid phenethyl ester is a potential therapeutic agent for oral cancer. Int. J. Mol. Sci. 2015, 16, 10748-10766. [CrossRef] [PubMed]

26. Haghiac, M.; Walle, T. Quercetin induces necrosis and apoptosis in SCC-9 oral cancer cells. Nutr. Cancer 2005, 53, 22. [CrossRef] [PubMed]

27. Iriti, M.; Varoni, E.M. Chemopreventive potential of flavonoids in oral squamous cell carcinoma in human studies. Nutrients 2013, 5, 2564-2576. [CrossRef] [PubMed]

28. Rossi, M.; Garavello, W.; Talamini, R.; Negri, E.; Bosetti, C.; Dal Maso, L.; Lagiou, P.; Tavani, A.; Polesel, J.; Barzan, L.; et al. Flavonoids and the risk of oral and pharyngeal cancer: A case-control study from Italy. Cancer Epidemiol. Biomark. Prev. 2007, 16, 1621-1625. [CrossRef]

29. Ong, C.S.; Tran, E.; Nguyen, T.T.; Ong, C.K.; Lee, S.K.; Lee, J.J.; Ng, C.P.; Leong, C.; Huynh, H. Quercetin-induced growth inhibition and cell death in nasopharyngeal carcinoma cells are associated with increase in Bad and hypophosphorylated retinoblastoma expressions. Oncol. Rep. 2004, 11, 727-733. [CrossRef]

30. Chan, G.C.; Cheung, K.W.; Sze, D.M. The immunomodulatory and anticancer properties of propolis. Clin. Rev. Allergy Immunol. 2013, 44, 262-273. [CrossRef] 
31. Ravishankar, D.; Rajora, A.K.; Greco, F.; Osborn, H.M. Flavonoids as prospective compounds for anti-cancer therapy. Int. J. Biochem. Cell. Biol. 2013, 45, 2821-2831. [CrossRef]

32. Hämäläinen, M.; Nieminen, R.; Vuorela, P.; Heinonen, M.; Moilanen, E. Anti-inflammatory effects of flavonoids: Genistein, kaempferol, quercetin, and daidzein inhibit STAT-1 and NF-kB activations, whereas flavone, isorhamnetin, naringenin, and pelargonidin inhibit only NF- $\mathrm{BB}$ activation along with their inhibitory effect on iNOS expression and NO production in activated macrophages. Mediat. Inflamm. 2007, 2007, 45673.

33. Zhang, M.; Swarts, S.G.; Yin, L.; Liu, C.; Tian, Y.; Cao, Y.; Swarts, M.; Yang, S.; Zhang, S.B.; Zhang, K.; et al. Antioxidant properties of quercetin. Adv. Exp. Med. Biol. 2011, 701, 283-289.

34. Mansuri, M.L.; Parihar, P.; Solanki, I.; Parihar, M.S. Flavonoids in modulation of cell survival signalling pathways. Genes. Nutr. 2014, 9, 400. [CrossRef] [PubMed]

35. Hou, D.X.; Kumamoto, T. Flavonoids as protein kinase inhibitors for cancer chemoprevention: Direct binding and molecular modelling. Antioxid. Redox Signal. 2010, 13, 691-719. [CrossRef]

36. Kang, N.J.; Shin, S.H.; Lee, H.J.; Lee, K.W. Polyphenols as small molecular inhibitors of signaling cascades in carcinogenesis Pharmacol. Ther. 2011, 130, 310-324. [CrossRef]

37. Amawi, H.; Ashby, C.R.; Tiwari, A.K. Cancer chemoprevention through dietary flavonoids: What's limiting? Chin. J. Cancer 2017, 36, 50. [CrossRef]

38. Kerimi, A.; Williamson, G. Differential Impact of Flavonoids on Redox Modulation, Bioenergetics, and Cell Signaling in Normal and Tumor Cells: A Comprehensive Review. Antioxid. Redox Signal. 2018, 29, 1633-1659. [CrossRef]

39. Chen, S.F.; Nien, S.; Wu, C.H.; Liu, C.L.; Chang, Y.C.; Lin, Y.S. Reappraisal of the anticancer efficacy of quercetin in oral cancer cells. J. Chin. Med. Assoc. 2013, 76, 146-152. [CrossRef] [PubMed]

40. Khan, I.; Paul, S.; Jakhar, R.; Bhardwaj, M.; Han, J.; Kang, S.C. Novel quercetin derivative TEF induces ER stress and mitochondriamediated apoptosis in human colon cancer HCT-116 cells. Biomed. Pharmacother. 2016, 84, 789-799. [CrossRef]

41. Su, Q.; Peng, M.; Zhang, Y.; Xu, W.; Darko, K.O.; Tao, T.; Huang, Y.; Tao, X.; Yang, X. Quercetin induces bladder cancer cells apoptosis by activation of AMPK signaling pathway. Am. J. Cancer Res. 2016, 15, 498-508.

42. Baruah, M.M.; Khandwekar, A.P.; Sharma, N. Quercetin modulates Wnt signaling components in prostate cancer cell line by inhibiting cell viability, migration, and metastases. Tumour. Biol. 2016, 37, 14025-14034. [CrossRef]

43. Lim, W.; Yang, C.; Park, S.; Bazer, F.W.; Song, G. Inhibitory Effects of Quercetin on Progression of Human Choriocarcinoma Cells Are Mediated Through PI3K/AKT and MAPK Signal Transduction Cascades. J. Cell. Physiol. 2016, 232, 1428-1440. [CrossRef]

44. Tang, S.M.; Deng, X.T.; Zhou, J.; Li, Q.P.; Ge, X.X.; Miao, L. Pharmacological basis and new insights of quercetin action in respect to its anti-cancer effects. Biomed. Pharmacother. 2020, 121, 109604. [CrossRef] [PubMed]

45. Yang, F.; Song, L.; Wang, H.; Wang, J.; Xu, Z.; Xing, N. Quercetin in prostate cancer: Chemotherapeutic and chemopreventive effects, mechanisms and clinical application potential (Review). Oncol. Rep. 2015, 33, 2659-2668. [CrossRef]

46. Febriansah, R.; Putri, D.D.; Nurulita, N.A.; Meiyanto, E.; Nugroho, A.E. Hesperidin as a preventive resistance agent in MCF-7 breast cancer cells line resistance to doxorubicin. Asian. Pac. J. Trop. Biomed. 2014, 4, 228-233. [CrossRef]

47. Banjerdpongchai, R.; Wudtiwai, B.; Khaw-On, P.; Rachakhom, W.; Duangnil, N.; Kongtawelert, P. Hesperidin from Citrus seed induces human hepatocellular carcinoma HepG2 cell apoptosis via both mitochondrial and death receptor pathways. Tumour. Biol. 2016, 37, 227-237. [CrossRef] [PubMed]

48. Birsu Cincin, Z.; Unlu, M.; Kiran, B.; Sinem Bireller, E.; Baran, Y.; Cakmakoglu, B. Anti-proliferative, apoptotic and signal transduction effects of hesperidin in non-small cell lung cancer cells. Cell. Oncol. 2015, 38, 195-224. [CrossRef] [PubMed]

49. Santos, B.L.; Silva, A.R.; Pitanga, B.P.; Sousa, C.S.; Grangeiro, M.S.; Fragomeni, B.O.; Coelho, P.L.; Oliveira, M.N.; Menezes-Filho, N.J.; Costa, M.F.; et al. Antiproliferative, proapoptotic and morphogenic effects of the flavonoid rutin on human glioblastoma cells. Food Chem. 2011, 15, 127. [CrossRef] 